University of Nebraska - Lincoln

DigitalCommons@University of Nebraska - Lincoln

Public Health Resources

Public Health Resources

2006

West Nile Virus Quantification In Feces Of Experimentally Infected American And Fish Crows

\author{
Aaron Kipp \\ Centers for Disease Control and Prevention \\ Jennifer Lehman \\ Centers for Disease Control and Prevention \\ Richard Bowen \\ Colorado State University \\ Patricia Fox \\ Colorado State University \\ Michael Stephens \\ Bolling Air Force Base \\ See next page for additional authors
}

Follow this and additional works at: https://digitalcommons.unl.edu/publichealthresources

Part of the Public Health Commons

Kipp, Aaron; Lehman, Jennifer; Bowen, Richard; Fox, Patricia; Stephens, Michael; Klenk, Kaci; Komar, Nicholas; and Bunning, Michel, "West Nile Virus Quantification In Feces Of Experimentally Infected American And Fish Crows" (2006). Public Health Resources. 178.

https://digitalcommons.unl.edu/publichealthresources/178

This Article is brought to you for free and open access by the Public Health Resources at DigitalCommons@University of Nebraska - Lincoln. It has been accepted for inclusion in Public Health Resources by an authorized administrator of DigitalCommons@University of Nebraska - Lincoln. 


\section{Authors}

Aaron Kipp, Jennifer Lehman, Richard Bowen, Patricia Fox, Michael Stephens, Kaci Klenk, Nicholas Komar, and Michel Bunning 


\title{
WEST NILE VIRUS QUANTIFICATION IN FECES OF EXPERIMENTALLY INFECTED AMERICAN AND FISH CROWS
}

\author{
AARON M. KIPP, JENNIFER A. LEHMAN, RICHARD A. BOWEN, PATRICIA E. FOX, MICHAEL R. STEPHENS, \\ KACI KLENK, NICHOLAS KOMAR,* AND MICHEL L. BUNNING \\ Division of Vector-Borne Infectious Diseases, Centers for Disease Control and Prevention, Fort Collins, Colorado; Department of \\ Biomedical Sciences, Colorado State University, Fort Collins, Colorado; Office of the Surgeon General, United States Air Force, \\ Bolling Air Force Base, Washington, District of Columbia
}

\begin{abstract}
To better understand the potential environmental health risk presented by West Nile virus (WNV)contaminated feces, we quantified the amount of WNV present in the feces of experimentally infected American crows (Corvus brachyrhynchos) and fish crows (Corvus ossifragus). Peak fecal titers ranged from $10^{3.5}$ to $10^{8.8}$ plaque-forming units (PFU)/g for 10 American crows and from $10^{2.3}$ to $10^{6.4} \mathrm{PFU} / \mathrm{g}$ for 10 fish crows. The presence of infectious WNV in bird feces indicates a potential for direct transmission of WNV. Thus, handlers of sick or dead birds should take appropriate precautions to avoid exposure to fecal material.
\end{abstract}

\section{INTRODUCTION}

West Nile virus (WNV) is an emerging mosquito-borne flavivirus of public and veterinary health importance in North America and Europe. ${ }^{1,2}$ Since its emergence in North America in 1999, mortality in corvid species (including crows, jays, ravens, and magpies) has been the hallmark of the ongoing epidemic. ${ }^{1}$ Experimental infection of crow species determined that individual species respond to WNV infection differently in terms of viremia levels, mortality rates, and cloacal shedding. ${ }^{3}$ In this experiment, American crows (Corvus brachyrhynchos) in contact with infected cage mates became infected in the absence of vector-borne transmission, whereas fish crows (Corvus ossifragus) did not experience this type of direct transmission.

Evidence of WNV in cloacal swabs has been documented in 20 of 29 species of experimentally infected birds, including four corvid species. ${ }^{3-7}$ Furthermore, intestinal involvement in natural WNV infections was shown in 12 of 14 birds tested, including three corvid species. ${ }^{8}$ Certain species such as geese, chickens, and turkeys have little or no virus present on cloacal swabs, ${ }^{4-6,9}$ whereas American and fish crows have virus levels as high as $10^{5.8}$ and $10^{4.8}$ plaque-forming units (PFU), respectively, on antemortem cloacal swabs. ${ }^{3}$ However, these data do not directly indicate the viral concentration in feces.

WNV-contaminated fecal material may be infectious to people and animals. To better understand the potential environmental health risk presented by WNV-contaminated feces, we quantified the amount of WNV present in the feces of experimentally infected American and fish crows. We also compared the temporal dynamics of WNV shedding in feces with viremia profiles.

\section{MATERIALS AND METHODS}

Crow selection and infection. Ten American crows captured in Kansas and 10 fish crows captured in Maryland were transported to Colorado and allowed to acclimate to captivity for 2 weeks. The crows were marked with uniquely numbered aluminum bands. Seronegative status for WNV and St. Louis

* Address correspondence to Nicholas Komar, Division of VectorBorne Infectious Diseases, Centers for Disease Control and Prevention, PO Box 2087, Fort Collins, CO 80522. E-mail: nck6@cdc.gov encephalitis (SLE) virus was confirmed by the plaque reduction neutralization test using the NY99-4132 strain of WNV and the TBH-28 strain of SLE virus. ${ }^{10}$ Crows were moved to a biosafety level 3 facility for the remainder of the study. They were housed in cages (three to four crows per cage, separated by species) providing $>1 \mathrm{ft}^{2}$ of floor area per crow, and fed a mixture of high-quality dog food (Hill's Science Diet-Canine Growth Kibble, Topeka, KS) and vegetables cut in small pieces. Birds were fed and watered twice a day, and cages were cleaned daily. Both groups of crows were infected by subcutaneous inoculation in the axillary region with $0.1 \mathrm{~mL}$ of a suspension of WNV strain NY99-6625 (crow brain isolate passed once through Vero cell culture) containing $~ 4,000$ PFU.

Crows were observed twice a day, and blood and fecal samples were collected daily for 14 days post-inoculation (DPI). Crows that appeared seriously ill at any time during the 2 weeks of observation were killed in accordance with approved animal use protocols. All surviving crows were killed at 15 DPI. Care and maintenance of all crows met or exceeded the National Institutes of Health guidelines for the humane use of laboratory animals.

Blood collection and testing. Blood samples of $0.2 \mathrm{~mL}$ were drawn from the jugular or brachial vein and placed in a vial containing $0.9 \mathrm{~mL}$ of BA-1 diluent (M199-Hank's salts with L-glutamine, $0.05 \mathrm{~mol} / \mathrm{L}$ Tris- $\mathrm{HCl}, \mathrm{pH} 7.5,1 \%$ bovine serum albumin, $\mathrm{pH} 7.0,0.35 \mathrm{~g} / \mathrm{L}$ sodium bicarbonate, $100 \mathrm{units} / \mathrm{mL}$ penicillin, $100 \mu \mathrm{g} / \mathrm{mL}$ streptomycin, $1 \mu \mathrm{g} / \mathrm{mL}$ fungizone). Samples were stored at $-70^{\circ} \mathrm{C}$. To determine viremia titers, blood samples were thawed, centrifuged, and titrated by Vero plaque assay, ${ }^{10}$ using an inoculation volume of $0.1 \mathrm{~mL}$ in duplicate, which provided a detection limit of $10^{1.7} \mathrm{PFU} / \mathrm{mL}$ serum. For the purposes of calculating means, any titers $<10^{1.7} \mathrm{PFU} / \mathrm{mL}$ were considered to be $0 \mathrm{PFU} / \mathrm{mL}$.

Fecal collection and testing. After blood collection, birds were placed for 1 hour in individual, raised cages with wax paper beneath to collect feces. Individual fecal samples were collected by removing, weighing, and transferring $0.1 \mathrm{~g}$ of feces to a vial containing $0.9 \mathrm{~mL}$ of BA-1 diluent and stored at $-70^{\circ} \mathrm{C}$. To determine virus content, the samples were thawed, vortexed for 10 seconds, and centrifuged at 3,700 rpm for 5 minutes using a Beckman GS-6R centrifuge (Ramsey, $\mathrm{MN})$. Supernatants were titrated by Vero plaque assay using duplicate $0.1-\mathrm{mL}$ inocula, which provided a detection limit of $10^{1.7} \mathrm{PFU} / \mathrm{g}$ feces. As stated above, any titers $<10^{1.7} \mathrm{PFU} / \mathrm{g}$ were considered to be zero during analysis. 


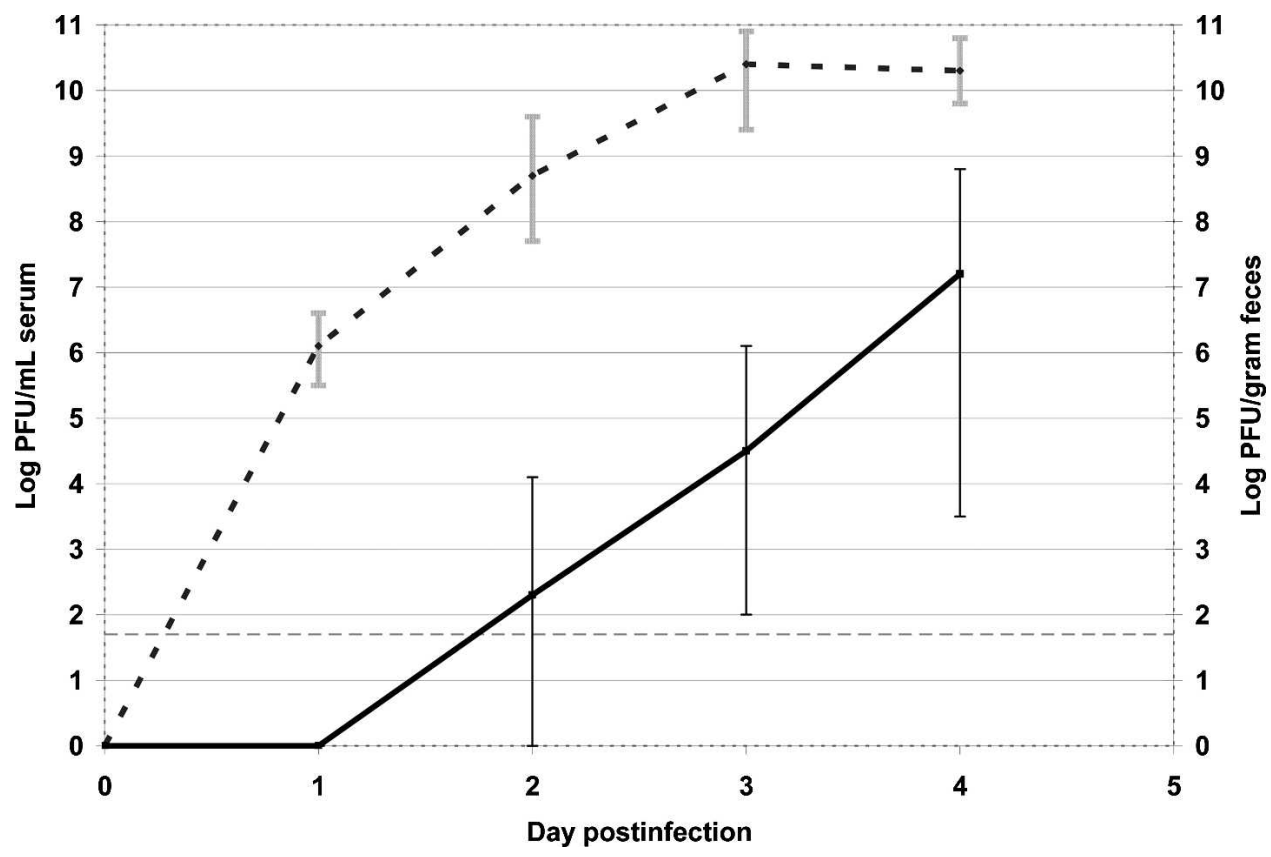

FIGURE 1. Mean WNV viremia (dashed line) and fecal (solid line) titers in 10 American crows by day post-inoculation (DPI). All crows succumbed by 5 DPI. Broad, light-colored vertical bars indicate the range of viremia titers; thin, dark-colored bars indicate the range of fecal titers. Dashed, horizontal line indicates the threshold of plaque assay detection $\left(1.7 \log _{10} \mathrm{PFU} / \mathrm{mL}\right.$ or gram).

\section{RESULTS}

American crows. Viremias were detected in all American crows from 1 DPI through 4 DPI, with termination occurring at 4 or 5 DPI. Peak viremias for individual crows ranged from $10^{9.8}$ to $10^{10.9} \mathrm{PFU} / \mathrm{mL}$ serum and peaked at 3 or 4 DPI. WNV in feces was first detected at 2 or 3 DPI and continued for 2-3 days until death or euthanization. Peak fecal titers for individual crows ranged from $10^{3.5}$ to $10^{8.8} \mathrm{PFU} / \mathrm{g}$, and peak titers were observed in 9 of 10 crows at 4 DPI. Mortality was $100 \%$ and occurred at 4 DPI, with the exception of one crow at 5 DPI. Mean fecal titers rose concurrently with mean viremia titers and peaked at 4 DPI, whereas mean viremia titers peaked at 3 DPI (Figure 1).

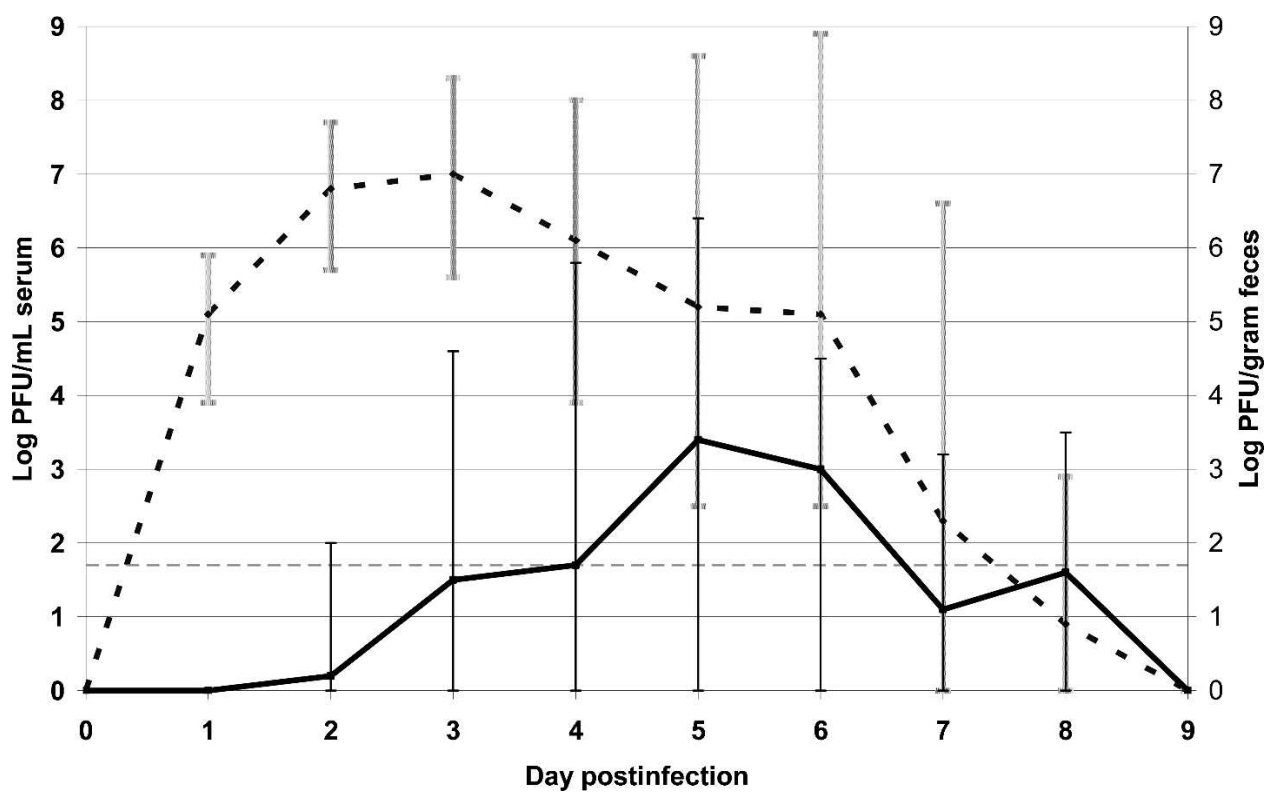

Figure 2. Mean WNV viremia (dashed line) and fecal (solid line) titers in 10 fish crows by day post-inoculation (DPI). Sample sizes for determination of mean viremia titers diminished because of mortality after 6 DPI as follows: 7 DPI, $N=8 ; 8$ DPI, $N=6 ; 9$ DPI, $N=4$. Sample sizes for determination of mean fecal titers match those for viremia titers except for 6 DPI, when three samples were not obtained and $N=7$. Broad, light-colored vertical bars indicate the range of viremia titers; thin, dark-colored bars indicate the range of fecal titers. No titers were detected in surviving birds beginning at 9 days; hence, data are shown only through day 9 . Dashed, horizontal line indicates the threshold of plaque assay detection $\left(1.7 \log _{10} \mathrm{PFU} / \mathrm{mL}\right.$ or gram). 
Fish crows. Viremia was present in all fish crows during the first 6 days of sampling with no virus detectable in surviving crows beyond 7 DPI. The peak viremia for individual crows ranged from $10^{5.9}$ to $10^{8.9} \mathrm{PFU} / \mathrm{mL}$ serum and peaked at a mean of 2.9 DPI (range: 2-6 DPI). WNV in feces was first detected at a mean of 3.6 DPI (range: 2-5 DPI). The mean period of WNV shedding was 4 days (range: $2-6$ days). Peak fecal titers for individual fish crows ranged from $10^{2.3}$ to $10^{6.4}$ PFU/g, and titers peaked at a mean of 5 DPI (range: 3-8 DPI). Mortality was $70 \%$ and occurred at a mean of 7.9 DPI (range: 6-13 DPI). One crow succumbed at 13 DPI, but viremia and fecal shedding were not detected after 6 and 8 DPI, respectively. Mean fecal titers rose gradually and peaked at 5 DPI, whereas mean viremia titers peaked 2 days earlier at 3 DPI (Figure 2). By 9 DPI, no viremia or fecal shedding was detected in surviving crows.

\section{DISCUSSION}

This study quantified WNV shed in the feces of laboratoryinfected American and fish crows. WNV titers per gram of fresh feces in both species were observed to be 2- to 3-fold higher than reported for cloacal swabs. ${ }^{3}$ Fecal titers reached levels $>10^{5} \mathrm{PFU} / \mathrm{g}$ in $90 \%$ of the American crows and $20 \%$ of the fish crows studied. Previous studies have shown that, in a laboratory setting, American crows can become infected by ingesting $10^{5}$ PFU of WNV and that non-vector-borne transmission occurs between infected American crows and uninfected cagemates. ${ }^{3,11}$ These observations and our findings of high fecal titers among American crows indicate that the fecal-oral route could facilitate virus transmission among American crows. This seems less likely among fish crows, which develop lower fecal titers, but cannot be ruled out given observations of fish crow titers surpassing $10^{5} \mathrm{PFU} / \mathrm{g}$ of feces. Whether fecal-oral transmission occurs among crows in the wild is unknown. However, crows often roost communally at high density. ${ }^{12}$ The risk of fecal-oral transmission in these communal roosts may be increased. WNV viability in crow feces is not known. However, WNV viability in chicken feces is reduced $99 \%$ after 24 hours. ${ }^{4}$ In fish crows, mean fecal titers peaked 2 days after mean viremia titers peaked, indicating that, although fish crows may have begun to clear circulating virus, large amounts of virus were shed for an additional 2 days before finally declining.

Fecal shedding of WNV by crows indicates a potential for direct transmission of WNV through contact with feces. The role of viral shedding in WNV transmission to birds or other vertebrates requires further research. Studies have not evaluated the quantity of virus or conditions necessary to infect humans or other primates through contact with WNVinfected feces. However, the presence of infectious WNV in bird feces warrants that handlers of sick or dead birds avoid exposure to fecal material.
Received February 8, 2005. Accepted for publication June 24, 2006.

Acknowledgments: The authors thank the following for support of this study: The American Bird Conservancy, Maryland and Kansas Departments of Wildlife, Brent Davis, Jason Velez, Brian Ortman, Paul Gordy, and Paula Schneider.

Authors' addresses: A. M. Kipp, The University of North Carolina at Chapel Hill, School of Public Health, Department of Epidemiology, McGavran-Greenberg Hall, CB\#7435, Chapel Hill, NC 27599-7435. J. A. Lehman and N. Komar, Division of Vector-Borne Infectious Diseases, Centers for Disease Control and Prevention, PO Box 2087, Fort Collins, CO 80522, E-mail: jalehman@cdc.gov. R. A. Bowen and M. R. Stephens, Department of Biomedical Sciences, Colorado State University, Fort Collins, CO 80523. P. E. Fox, Wisconsin Division of Public Health, Communicable Disease Epidemiology Section, PO Box 2659, Madison, WI 53701. K. Klenk, United States Department of Agriculture, Animal and Plant Health Inspection Service, National Wildlife Research Center, 4101 LaPorte Ave., Ft. Collins, CO 80524. M. L. Bunning, 59 Aerospace Medicine Squadron, 1515 Truemper Street, Lackland AFB, TX 78236.

\section{REFERENCES}

1. Campbell GL, Marfin AA, Lanciotti RS, Gubler DJ, 2002. West Nile virus. Lancet 2: 519-529.

2. Hubálek Z, Halouzka J, 1999. West Nile Fever-a reemerging mosquito-borne viral disease in Europe. Emerg Infect Dis 5: 643-650.

3. Komar N, Langevin S, Hinten S, Nemeth N, Edwards E, Hettler D, Davis B, Bowen R, Bunning M, 2003. Experimental infection of North American birds with the New York 1999 strain of West Nile virus. Emerg Infect Dis 9: 311-322.

4. Langevin SA, Bunning M, Davis B, Komar N, 2001. Experimental infection of chickens as candidate sentinels for West Nile virus. Emerg Infect Dis 7: 726-729.

5. Swayne DE, Beck JR, Smith CS, Shieh W-J, Zaki SR, 2001. Fatal encephalitis and myocarditis in young domestic geese (Anser anser domesticus) caused by West Nile virus. Emerg Infect Dis 7: 751-753.

6. Swayne DE, Beck JR, Zaki S, 2000. Pathogenicity of West Nile virus for turkeys. Avian Dis 44: 932-937.

7. Nemeth N, Edwards E, Gould D, Bowen R, Komar N, 2006. Natural and experimental West Nile virus infection in five raptor species. $J$ Wildl Dis 42: 1-13.

8. Steele KE, Linn MJ, Schoepp RJ, Komar N, Geisbert TW, Manduca RM, Calle PP, Raphael BL, Clippinger TL, Larsen TK, Smith J, Lanciotti RS, Panella NA, McNamara TS, 2000. Pathology of fatal West Nile virus infections in native and exotic birds during the 1999 outbreak in New York City, New York. Vet Pathol 37: 208-224.

9. Senne DA, Pedersen JC, Hutto DL, Taylor WD, Schmitt BJ, Panigrahy B, 2000. Pathogenicity of West Nile virus in chickens. Avian Dis 44: 642-649.

10. Beaty BJ, Calisher CH, Shope RE, 1995. Arboviruses. Lennette EH, Lennette DA, eds. Diagnostic Procedures for Viral, Rickettsial, and Chlamydial Infections. Seventh edition. Washington, DC: American Public Health Association, 189212.

11. McLean RG, Ubico SR, Docherty DE, Hansen WR, Sileo L, McNamara TS, 2001. West Nile virus transmission and ecology in birds. Ann N Y Acad Sci 951: 54-57.

12. Verbeek NAM, Caffrey C, 2002. American crow (Corvus brachyrynchos). Poole A, Gill F, eds. The Birds of North America. No. 647. Philadelphia: The Birds of North America, 1-36. 